\title{
The climate signal recorded in the oxygen-isotope, accumulation and major-ion time series from the Eclipse ice core, Yukon Territory, Canada
}

\author{
Cameron P. WAKE, ${ }^{1}$ Kaplan YAlCin, ${ }^{1}$ Niels S. GUNDESTRUP ${ }^{2}$ \\ ${ }^{1}$ Climate Change Research Center, Institute for the Study of Earth, Oceans, and Space, University of New Hampshire, Durham, NH 03824, U.S.A. \\ E-mail: cameron.wake@unh.edu \\ ${ }^{2}$ Department of Geophysics, University of Copenhagen, Rockefeller Complex, Fuliane Maries Vej. 30, DK-2100 Copenhagen, Denmark
}

\begin{abstract}
The high accumulation rate, nearly complete preservation and detailed chronology of the Eclipse ice core, Yukon Territory, Canada, are well suited for comparison of the glaciochemical record with instrumental time series of temperature, precipitation and sea-level pressure. Results of cross-correlation analysis of instrumental temperature records with the Eclipse $\delta^{18} \mathrm{O}$ time series reveal a significant positive relationship between summertime $\delta^{18} \mathrm{O}$ at Eclipse and summer (April-September) temperatures in northwestern North America. The results indicate that the Eclipse $\delta^{18} \mathrm{O}$ time series provides a better proxy for regional temperature than does the $\delta^{18} \mathrm{O}$ time series from the Mount Logan ice-core record for which only negative correlations were found. Winter accumulation at Eclipse is significantly correlated with several sites in Alaska, but not with any sites in the Yukon. The $\delta^{18} \mathrm{O}$, accumulation and glaciochemical time series also display significant correlations with the Northern Hemisphere sea-level pressure dataset, especially between wintertime sulfate and nitrate concentrations at Eclipse and the intensity of the wintertime Siberian high and Aleutian and Icelandic lows. These results suggest that year-to-year variability in the deposition of pollutants at Eclipse can be linked to changes in atmospheric circulation, while longterm trends can be explained by changes in source strength.
\end{abstract}

\section{INTRODUCTION}

Our understanding of natural climate variability over the past several hundred years and the identification of humaninduced climate change in the Arctic is hampered by the lack of long-term instrumental records from this region. To supplement the instrumental record and enhance our understanding of natural climate variability, multivariate climate records can be developed through the collection and analysis of ice cores recovered from suitably located glaciers and polar ice caps. Preserved in glacial ice is a time series of precipitation chemistry and dry deposition reflecting changes in temperature, precipitation and atmospheric circulation. However, the exact links between the ice-core records, the instrumental record and other paleoclimate records are often unclear.

While a growing number of ice-core records have been recovered from Greenland and the eastern Canadian Arctic (e.g. Koerner and Fisher, 1990; Hammer and others, 1997; Fisher and others, 1998; Grumet and others, 2001), the icecore record from Mount Logan long remained the only one recovered from northwest North America. The $103 \mathrm{~m}$ core was recovered in 1980 from an elevation of $5340 \mathrm{~m}$ on the summit plateau of Mount Logan $\left(60.35^{\circ} \mathrm{N}, 140.30^{\circ} \mathrm{W}\right)$, Saint Elias Mountains, southwest Yukon Territory, Canada (Holdsworth and others, 1984; Holdsworth and Peake, 1985). Unfortunately, the oxygen isotope record from Mount Logan does not cross-correlate well with regional instrumental records of temperature (Holdsworth and others, 1992), as the Mount Logan ice-core site samples primarily free tropospheric air masses with a distinctly different stable-isotope fractionation history compared to air masses present at the lower-elevation meteorological stations (Holdsworth and others, 1991; Holdsworth and Krouse, 2002). However, analysis of the accumulation time series from Mount Logan shows strong correlation with instrumental precipitation records from Japan (Holdsworth and others, 1992). In addition, due to its location near the

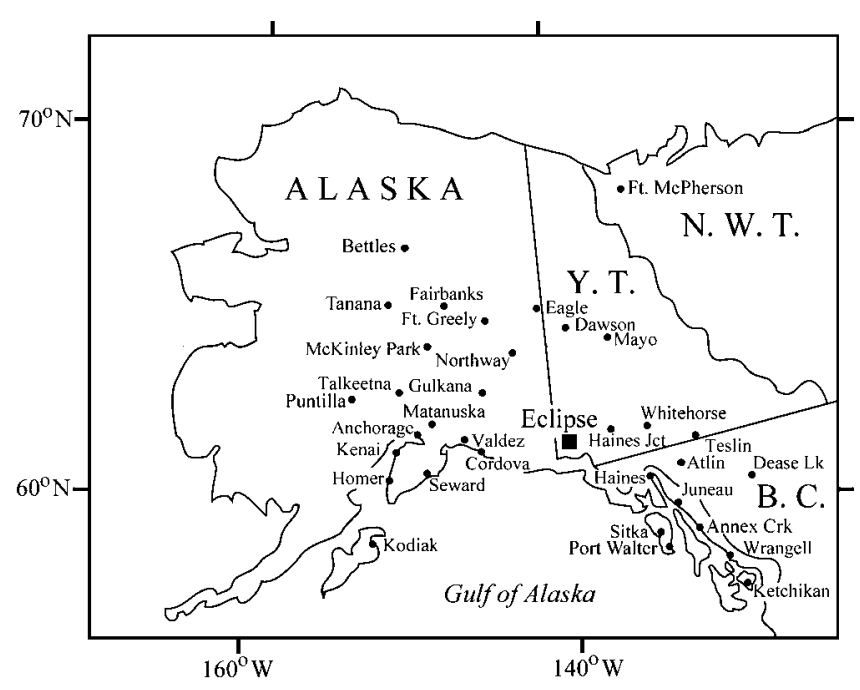

Fig. 1. Location map for Global Historical Climatological Network (GHCN) meteorological stations whose data are used in this work (small black circles) and the Eclipse Icefield (large black square). 

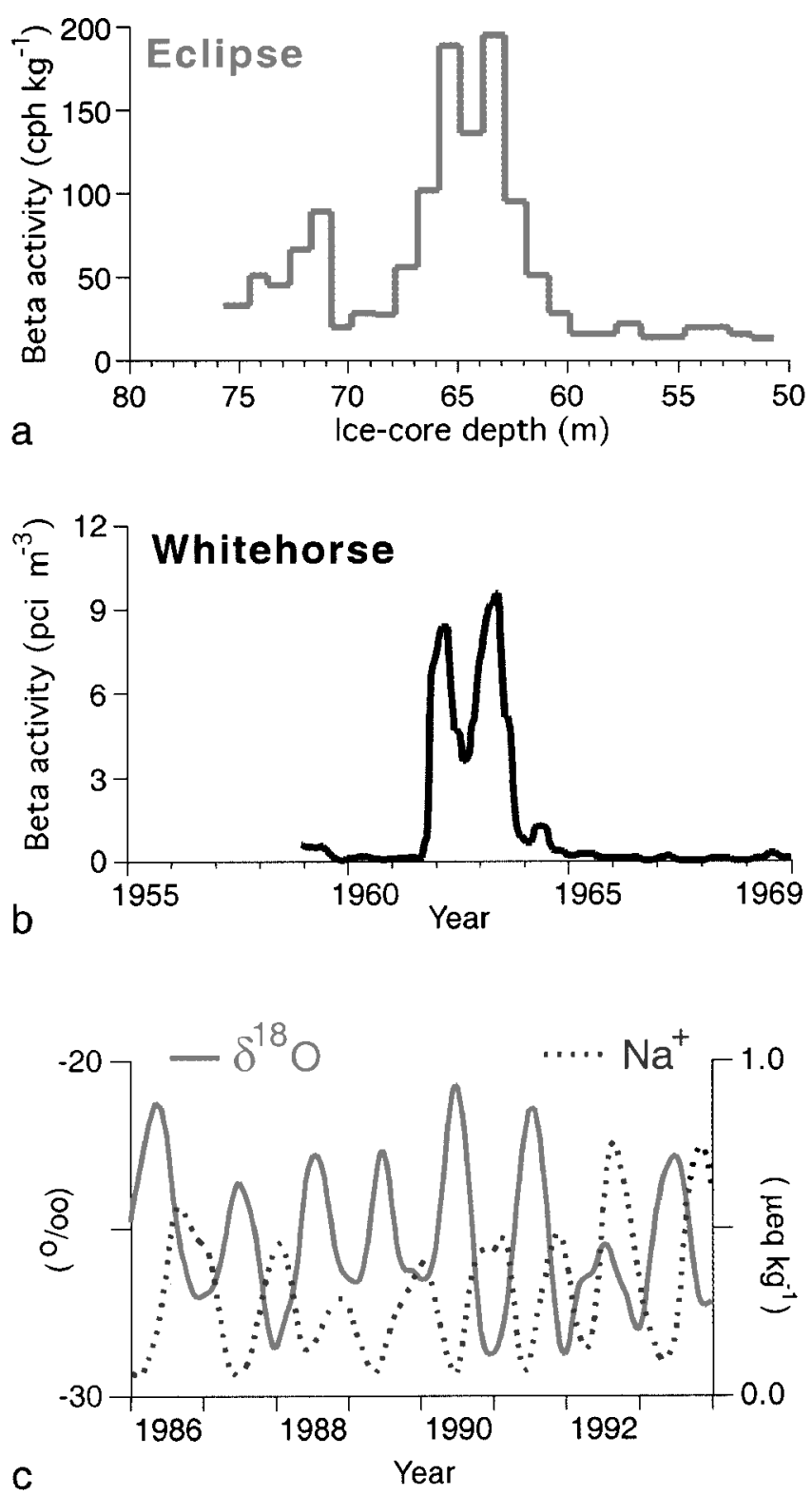

Fig. 2. Detail of records used to develop a depth-age relationship for the Eclipse core: $(a, b)$ beta-activity record from the Eclipse ice core (a) and from air samples collected at Whitehorse, Fukon Territory (b) (after Holdsworth and others, 1984); (c) seasonal signals in the $\delta^{18} \mathrm{O}$ and $\mathrm{Na}^{+}$records smoothed using a robust spline.

500 mbar height, the Mount Logan record is uniquely situated for evaluating the extratropical response to El NiñoSouthern Oscillation (ENSO) (Moore and others, 2001).

To provide new insights into the temporal variability of precipitation chemistry and develop a broader array of proxy climate records for northwestern North America, a $160 \mathrm{~m}$ ice core was collected from Eclipse Icefield (Fig. 1; $60.51^{\circ} \mathrm{N}, 139.47^{\circ} \mathrm{W} ; 3017 \mathrm{~m}$ a.s.l.) in the Saint Elias Range, Yukon Territory. The Eclipse site is $45 \mathrm{~km}$ northeast of and more than $2 \mathrm{~km}$ lower than the Mount Logan drill site, with an accumulation rate nearly five times greater. Due to its lower elevation, the Eclipse site samples air masses distinctly different from those sampled by the Mount Logan site, with different source inputs and transport histories (Holdsworth and others, 1988; Yalcin and Wake, 2001). The high accumulation rate and nearly complete preservation at the Eclipse site provides an excellent opportunity to compare the ice-core record with instrumental time series of tempera-
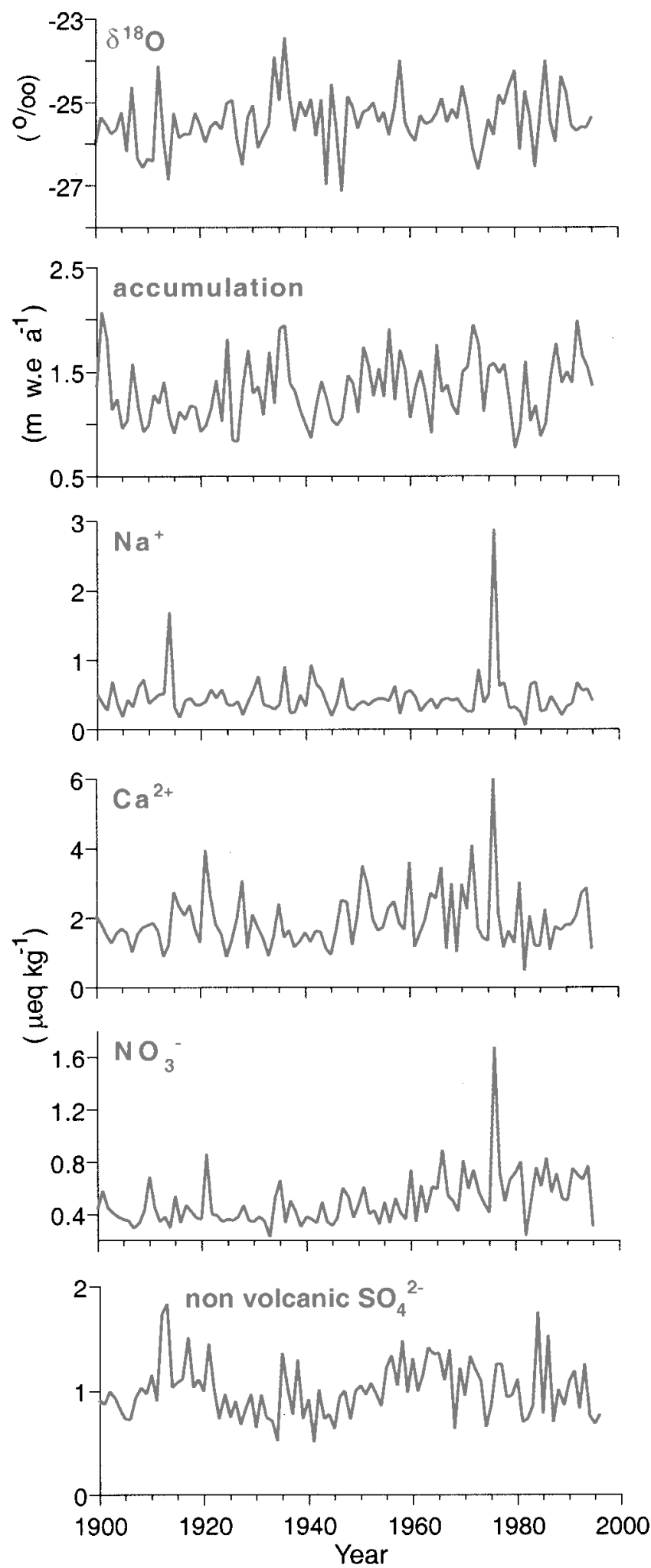

Fig. 3. Annualized time series developed from physical and chemical analysis of the Eclipse ice core.

ture, precipitation and sea-level pressure (SLP) and determine the extent to which the Eclipse glaciochemical, isotopic and accumulation time series can be considered a representative proxy for temperature, precipitation and atmospheric circulation in the region.

\section{METHODS}

The $160 \mathrm{~m}$ firn/ice core was recovered from Eclipse Icefield in summer 1996 (Blake and others, 1998) and shipped frozen 
Table 1. Monthly temperature and precipitation records from meteorological stations surrounding the Saint Elias Range used in our analysis

\begin{tabular}{|c|c|c|c|c|c|c|c|}
\hline \multirow[t]{2}{*}{ Station } & \multirow[t]{2}{*}{ Location } & \multicolumn{3}{|c|}{ Temperature } & \multicolumn{3}{|c|}{ Precipitation } \\
\hline & & Begin & End & $\%$ miss & Begin & End & $\%$ miss \\
\hline Kodiak, AK & $57.75^{\circ} \mathrm{N}, 152.50^{\circ} \mathrm{W}$ & 1915 & 1996 & 1.8 & 1899 & 1990 & 4.0 \\
\hline Homer, AK & $59.63^{\circ} \mathrm{N}, 151.50^{\circ} \mathrm{W}$ & 1932 & 1996 & 6.3 & 1932 & 1999 & 5.9 \\
\hline Kenai, AK & $60.52^{\circ} \mathrm{N}, 151.25^{\circ} \mathrm{W}$ & 1899 & 1996 & 37.8 & $\mathrm{~N} / \mathrm{A}$ & $\mathrm{N} / \mathrm{A}$ & $\mathrm{N} / \mathrm{A}$ \\
\hline Seward, AK & $60.12^{\circ} \mathrm{N}, 149.45^{\circ} \mathrm{W}$ & 1908 & 1990 & 7.1 & $\mathrm{~N} / \mathrm{A}$ & $\mathrm{N} / \mathrm{A}$ & $\mathrm{N} / \mathrm{A}$ \\
\hline Valdez, AK & $61.13^{\circ} \mathrm{N}, 146.35^{\circ} \mathrm{W}$ & 1917 & 1996 & 12.0 & $\mathrm{~N} / \mathrm{A}$ & $\mathrm{N} / \mathrm{A}$ & $\mathrm{N} / \mathrm{A}$ \\
\hline Cordova, AK & $60.50^{\circ} \mathrm{N}, 145.50^{\circ} \mathrm{W}$ & 1909 & 1996 & 7.3 & 1942 & 1990 & 5.3 \\
\hline Haines, AK & $59.24^{\circ} \mathrm{N}, 135.44^{\circ} \mathrm{W}$ & 1925 & 1990 & 3.8 & 1925 & 1981 & 6.3 \\
\hline Juneau & $58.37^{\circ} \mathrm{N}, 134.58^{\circ} \mathrm{W}$ & 1943 & 1996 & 2.3 & 1899 & 1990 & 2.8 \\
\hline Annex Creek, AK & $58.32^{\circ} \mathrm{N}, 134.10^{\circ} \mathrm{W}$ & 1917 & 1989 & 3.7 & $\mathrm{~N} / \mathrm{A}$ & NIA & $\mathrm{N} / \mathrm{A}$ \\
\hline Sitka, AK & $57.07^{\circ} \mathrm{N}, 135.35^{\circ} \mathrm{W}$ & 1899 & 1989 & 2.4 & 1842 & 1989 & 12.0 \\
\hline Little Port Walter, AK & $56.39^{\circ} \mathrm{N}, 134.66^{\circ} \mathrm{W}$ & 1936 & 1990 & 1.5 & $\mathrm{~N} / \mathrm{A}$ & $\mathrm{N} / \mathrm{A}$ & $\mathrm{N} / \mathrm{A}$ \\
\hline Wrangell, AK & $56.50^{\circ} \mathrm{N}, 132.40^{\circ} \mathrm{W}$ & 1917 & 1990 & 7.9 & 1917 & 1989 & 7.1 \\
\hline Ketchikan, AK & $55.37^{\circ} \mathrm{N}, 131.72^{\circ} \mathrm{W}$ & 1910 & 1990 & 5.3 & $\mathrm{~N} / \mathrm{A}$ & $\mathrm{N} / \mathrm{A}$ & $\mathrm{N} / \mathrm{A}$ \\
\hline Bettles, AK & $66.90^{\circ} \mathrm{N}, 151.50^{\circ} \mathrm{W}$ & 1944 & 1996 & 1.7 & 1944 & 1990 & 1.2 \\
\hline Tanana. AK & $65.20^{\circ} \mathrm{N}, 152.10^{\circ} \mathrm{W}$ & 1905 & 1990 & 8.3 & 1903 & 1989 & 2.5 \\
\hline Puntilla, AK & $62.10^{\circ} \mathrm{N}, 152.75^{\circ} \mathrm{W}$ & 1942 & 1990 & 8.2 & 1942 & 1981 & 14.4 \\
\hline Anchorage, AK & $61.17^{\circ} \mathrm{N}, 150.02^{\circ} \mathrm{W}$ & 1916 & 1996 & 1.5 & 1916 & 1990 & 1.6 \\
\hline Matanuska, AK & $61.60^{\circ} \mathrm{N}, 149.30^{\circ} \mathrm{W}$ & 1917 & 1990 & 3.8 & 1917 & 1989 & 3.0 \\
\hline Talkeetna, AK & $62.30^{\circ} \mathrm{N}, 150.10^{\circ} \mathrm{W}$ & 1918 & 1996 & 3.4 & 1918 & 1999 & 4.4 \\
\hline McKinley Park, AK & $63.70^{\circ} \mathrm{N}, 149.00^{\circ} \mathrm{W}$ & 1923 & 1990 & 3.4 & 1923 & 1989 & 5.8 \\
\hline Fairbanks Int'l, AK & $64.82^{\circ} \mathrm{N}, 147.87^{\circ} \mathrm{W}$ & 1929 & 1996 & 3.7 & $\mathrm{~N} / \mathrm{A}$ & $\mathrm{N} / \mathrm{A}$ & $\mathrm{N} / \mathrm{A}$ \\
\hline Fairbanks Univ., AK & $64.85^{\circ} \mathrm{N}, 147.87^{\circ} \mathrm{W}$ & 1904 & 1990 & 2.1 & 1905 & 1988 & 10.0 \\
\hline Fort Greeley, AK & $64.00^{\circ} \mathrm{N}, 145.73^{\circ} \mathrm{W}$ & 1941 & 1996 & 6.2 & $\mathrm{~N} / \mathrm{A}$ & $\mathrm{N} / \mathrm{A}$ & $\mathrm{N} / \mathrm{A}$ \\
\hline Gulkana, AK & $62.15^{\circ} \mathrm{N}, 145.45^{\circ} \mathrm{W}$ & 1910 & 1996 & 34.5 & 1942 & 1999 & 2.0 \\
\hline Northway, AK & $62.97^{\circ} \mathrm{N}, 141.94^{\circ} \mathrm{W}$ & 1942 & 1996 & 4.2 & 1942 & 1990 & 1.0 \\
\hline Eagle, AK & $64.79^{\circ} \mathrm{N}, 141.20^{\circ} \mathrm{W}$ & 1899 & 1990 & 28.4 & 1899 & 1981 & 21.5 \\
\hline Dawson, YT & $64.05^{\circ} \mathrm{N}, 139.13^{\circ} \mathrm{W}$ & 1897 & 1979 & 5.9 & 1897 & 1990 & 6.6 \\
\hline HainesJunction, YT & $60.77^{\circ} \mathrm{N}, 137.58^{\circ} \mathrm{W}$ & 1944 & 1985 & 5.6 & 1944 & 1980 & 4.3 \\
\hline Мayo, YT & $63.62^{\circ} \mathrm{N}, 135.87^{\circ} \mathrm{W}$ & 1924 & 1990 & 3.7 & 1925 & 1990 & 3.0 \\
\hline Fort McPherson, NWT & $67.40^{\circ} \mathrm{N}, 134.90^{\circ} \mathrm{W}$ & 1892 & 1977 & 30.6 & 1940 & 1977 & 41.0 \\
\hline Whitehorse, YT & $60.72^{\circ} \mathrm{N}, 135.07^{\circ} \mathrm{W}$ & 1942 & 1995 & 10.3 & 1942 & 1990 & 1.0 \\
\hline Teslin, YT & $60.17^{\circ} \mathrm{N}, 132.73^{\circ} \mathrm{W}$ & 1943 & 1989 & 11.3 & $\mathrm{~N} / \mathrm{A}$ & $\mathrm{N} / \mathrm{A}$ & $\mathrm{N} / \mathrm{A}$ \\
\hline Atlin, BC & $59.57^{\circ} \mathrm{N}, 133.70^{\circ} \mathrm{W}$ & 1899 & 1947 & 29.7 & 1899 & 1990 & 31.0 \\
\hline Dease Lake, BC & $58.42^{\circ} \mathrm{N}, 130.00^{\circ} \mathrm{W}$ & 1944 & 1990 & 3.9 & 1944 & 1990 & 7.3 \\
\hline
\end{tabular}

Notes: Data obtained from the U.S. National Oceanic and Atmospheric Administration GHCN. \%miss indicates percentage of missing data for the years listed. AK, Alaska;YT, Yukon Territory; NWT, Northwest Territories; BC, British Columbia. N/A, not available.

to the University of New Hampshire (UNH). The core was continuously sampled in $10 \mathrm{~cm}$ segments using stringent core-processing techniques to ensure that samples were contamination-free at the $\mathrm{ng} \mathrm{g}^{-1}$ level. Blanks prepared on a frequent basis showed no contamination of samples during processing of the core. Samples were analyzed for major ions $\left(\mathrm{Na}^{+}, \mathrm{NH}_{4}{ }^{+}, \mathrm{K}^{+}, \mathrm{Mg}^{2+}, \mathrm{Ca}^{2+}, \mathrm{Cl}^{-}, \mathrm{NO}_{3}{ }^{-}, \mathrm{SO}_{4}{ }^{2-}\right)$ using an ion chromatograph in a dedicated laboratory at $\mathrm{UNH}$, and for oxygen isotopes at the Department of Geophysics, University of Copenhagen, Denmark. A section of the core from 50 to $76 \mathrm{~m}$ depth was analyzed for beta activity.

Analysis of the ice-core beta-activity profile and comparison with real-time precipitation measurements from Whitehorse, Yukon Territory (Fig. 2a and b), shows clear identification of the 1961 and 1963 beta-activity peaks from atmospheric thermonuclear weapons testing. Average annual accumulation from 1963 to 1996 was $1.38 \mathrm{~m}$ w.e. Analysis of snow-pit samples collected during the summer drilling season indicates that $\delta^{18} \mathrm{O}$ values are heavier and $\mathrm{Na}^{+}$concentrations lower in summer snow. The seasonal variability of the $\delta^{18} \mathrm{O}$ signal in snow at Eclipse (heavier in summer, lighter in winter) is similar to that recorded in Greenland snow (Dansgaard, 1964), suggesting that the tem- perature at which the snow forms in the atmosphere is the dominant control on the oxygen isotope ratio preserved at the Eclipse site. Sodium peaks generally occur during the winter, likely as a result of increased wind speeds. The $\delta^{18} \mathrm{O}$ and $\mathrm{Na}^{+}$relationship $\left(\mathrm{Na}^{+}\right.$peaks coinciding with troughs in the $\delta^{18} \mathrm{O}$ record) are evident in the ice-core record, especially when smoothed slightly using a robust spline (Meeker and others, 1995) (Fig. 2c). The consistent seasonal signals recorded in these two time series provide the basis for the counting of annual layers and the identification of seasonal (summer and winter) layers in the ice-core record. Control on the depth-age relationship developed via annual-layer counting is provided by identification of nuclear weaponstesting fallout and $\mathrm{SO}_{4}{ }^{2-}$ reference horizons linked to known volcanic eruptions (Yalcin and Wake, in press). While it is difficult to quantify the dating uncertainty, we estimate it to be no more than \pm 1 year for the last 100 years based on our multiparameter approach and the high number of positively identified volcanic horizons. The annualized ice-core time series discussed in this paper are shown in Figure 3.

To compare the ice-core record with a variety of meteorological variables, we collected instrumental time series of monthly mean temperature and monthly precipita- 
Table 2. Correlation coefficients for ice core $\delta^{18} \mathrm{O}$ vs instrumental temperature records, and ice-core accumulation vs instrumental precipitation records

\begin{tabular}{|c|c|c|c|c|c|c|c|c|}
\hline \multirow[t]{2}{*}{ Station } & \multirow{2}{*}{$\begin{array}{l}\text { Number } \\
\text { of years }\end{array}$} & \multicolumn{3}{|c|}{$r\left(\delta^{I g} \mathrm{O}\right.$ vs temperature $)$} & \multirow{2}{*}{$\begin{array}{l}\text { Number } \\
\text { of years }\end{array}$} & \multicolumn{3}{|c|}{$r($ accumulation vs $p p t)$} \\
\hline & & Winter & Summer & Annual & & Winter & Summer & Anпиаl \\
\hline Kodiak, AK & 82 & & 0.26 & 0.23 & 92 & & & \\
\hline Homer, AK & 65 & & & & 58 & & & \\
\hline Kenai, AK & 98 & & 0.22 & & $\mathrm{~N} / \mathrm{A}$ & & & \\
\hline Seward, AK & 83 & & & & $\mathrm{~N} / \mathrm{A}$ & & & \\
\hline Valdez, AK & 80 & & & & $\mathrm{~N} / \mathrm{A}$ & & & \\
\hline Cordova, AK & 91 & & & & 48 & & & \\
\hline Haines, AK & 66 & & 0.25 & & 57 & & & \\
\hline Juneau & 54 & & & & 92 & & & \\
\hline Annex Creek, AK & 73 & & & & $\mathrm{~N} / \mathrm{A}$ & & & \\
\hline Sitka, AK & 91 & & & & 91 & & & 0.18 \\
\hline Little Port Walter, AK & 55 & & 0.21 & & $\mathrm{~N} / \mathrm{A}$ & & & \\
\hline Wrangell, AK & 74 & & 0.29 & & 73 & & & \\
\hline Ketchikan, AK & 81 & & 0.23 & 0.28 & $\mathrm{~N} / \mathrm{A}$ & & & \\
\hline Bettles, AK & 53 & 0.24 & 0.24 & & 47 & & & \\
\hline Tanana, AK & 86 & & 0.21 & & 87 & 0.19 & & \\
\hline Puntilla, AK & 49 & & 0.22 & & 40 & & & \\
\hline Anchorage, AK & 81 & & & & 75 & 0.25 & & \\
\hline Matanuska, AK & 74 & & 0.27 & & 73 & 0.29 & & \\
\hline Talkeetna, AK & 79 & & 0.23 & & 71 & & & \\
\hline McKinley Park, AK & 68 & & 0.29 & & 67 & 0.33 & & \\
\hline Fairbanks Int'l, AK & 68 & & & & $\mathrm{~N} / \mathrm{A}$ & & & \\
\hline Fairbanks Univ., AK & 87 & & 0.21 & & 84 & 0.33 & & 0.30 \\
\hline Fort Greeley, AK & 57 & & 0.26 & & $\mathrm{~N} / \mathrm{A}$ & & & \\
\hline Gulkana, AK & 87 & & & & 48 & & & 0.22 \\
\hline Northway, AK & 55 & & & & 49 & 0.20 & & -0.24 \\
\hline Eagle, AK & 45 & & & & 82 & 0.21 & & \\
\hline Dawson, YT & 83 & & & & 94 & & & \\
\hline HainesJunction, YT & 42 & 0.32 & & & 37 & & & \\
\hline Мayo, YT & 67 & & 0.28 & & 64 & & & \\
\hline Fort McPherson, NWT & 71 & & & & 72 & & & \\
\hline Whitehorse, YT & 50 & & 0.28 & & 49 & & & \\
\hline Teslin, YT & 47 & & 0.33 & & $\mathrm{~N} / \mathrm{A}$ & & & \\
\hline Atlin, BC & 92 & & & & 92 & & & \\
\hline Dease Lake, BC & 47 & & & & $\mathrm{~N} / \mathrm{A}$ & & & \\
\hline EOF1-Temperature & 46 & & 0.30 & & $\mathrm{~N} / \mathrm{A}$ & & & \\
\hline
\end{tabular}

Notes: Only $r$ values significant at the $P=0.05$ level for $\delta^{18} \mathrm{O} /$ temperature data and at the $P=0.10$ level for the accumulation/precipitation data are listed. AK, Alaska; YT, Yukon Territory; NWT, Northwest Territories; BC, British Columbia. N/A, not available.

tion from a range of stations surrounding the Saint Elias Mountains (Table 1; Fig. 1). These monthly time series were converted to both annual (January-December) and seasonal (October-March; April-September) resolutions for comparison with our glaciochemical record on an annual and seasonal basis. Missing months in the instrumental records were filled in with the long-term average for that month; years with more than half the months missing were excluded from our analyses. Cross-correlation analysis was performed individually between each instrumental record and the Eclipse ice-core record over the maximum period the records overlapped. This overlap was 45-92 years for temperature records, and 37-92 years for the precipitation records. Instrumental data series shorter than 35 years were not used in our analysis.

We also developed a regional temperature record using data from all stations (31 total) that had records extending from at least 1944 to 1989. This was accomplished by running an empirical orthogonal function (EOF) analysis on the annual, summer and winter records. The first EOF (EOFl-Temperature) explains $71 \%, 54 \%$ and $81 \%$ of the variability in the data for the annual, summer and winter records, respectively. A similar analysis was performed on the precipitation data; however, the first EOF explained at most $25 \%$ of the variability in the data, and, due to the high spatial variability in these precipitation data, we have not used the precipitation EOF as a regional record. The Eclipse glaciochemical record was also compared with gridded $\left(5^{\circ} \times 5^{\circ}\right)$ Northern Hemisphere SLP data over the period 1899-1995 (after Trenberth and Paolino, 1980). Seasonal SLPs for winter (December-February) and summer (June-August) were compared with winter and summer records from the Eclipse ice core.

\section{RESULTS AND DISGUSSION}

\section{Eclipse $\delta^{18} \mathrm{O}$ and instrumental temperature records}

The results of cross-correlation analysis of instrumental temperature and precipitation records with the Eclipse $\delta^{18} \mathrm{O}$ and net accumulation time series are presented in Table 2. The most widespread significant positive correlations between the Eclipse $\delta^{18} \mathrm{O}$ and instrumental temperature occur during the summertime (Fig. 4). There also exists a significant positive correlation between "summer" EOF1-Temperature and the summertime $\delta^{18} \mathrm{O}$ record. The 

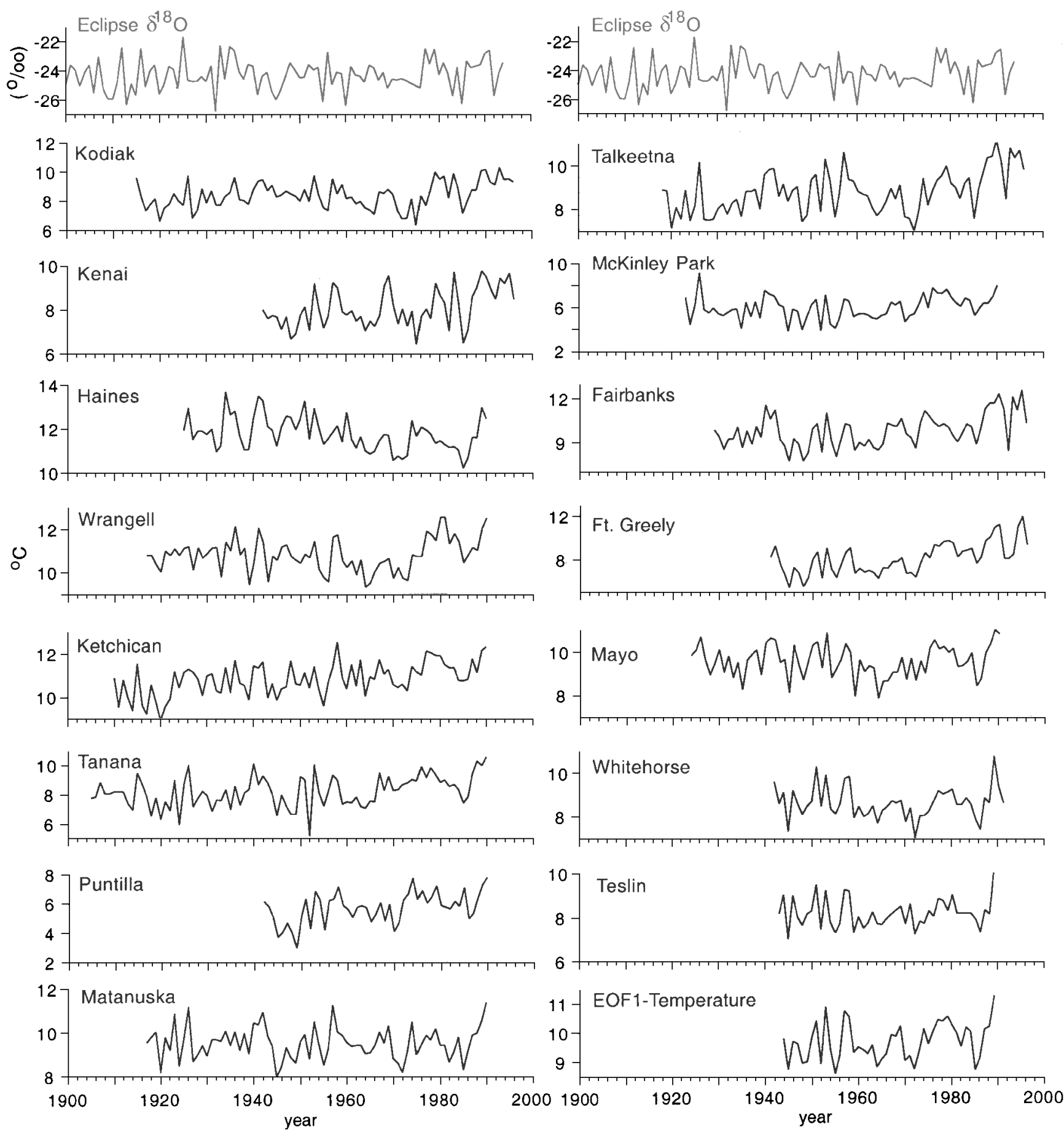

Fig. 4. Comparison of time series of summertime Eclipse $\delta^{\not B} O$ (top) and "summer" (April-September) temperatures from meteorological stations that show a correlation coefficient greater than 0.2 with the $\delta^{18} \mathrm{O}$ record.

results indicate that summertime $\delta^{18} \mathrm{O}$ signals at Eclipse represent $5-10 \%$ of the temperature variability in a broad coastal region extending from Ketchikan to Kodiak, to the interior of Alaska north of the Alaska Range and at inland locations in the Yukon Territory and northern British Columbia. While the $\delta^{18} \mathrm{O} /$ summer-temperature correlations are not strong, they are significant and indicate that the summer stable-isotope signals preserved at Eclipse provide a record that is more closely linked to temperatures at low-elevation sites compared to the Mount Logan record.

All of the correlation analyses were also done with a lag of \pm lyear. None of the correlation coefficients discussed here improved with this lag, suggesting that our depth-age relationship is reasonably accurate.

\section{Eclipse accumulation and instrumental precipitation records}

Eclipse accumulation is significantly positively correlated primarily with inland sites in Alaska during the winter, but shows no significant correlation with nearby locations. While the cluster of sites with a significant correlation suggests a link between wintertime snow accumulation at Eclipse and in central Alaska, the Eclipse record explains only 4-10\% of the variability in Alaska wintertime precipitation. Our EOF analysis of regional precipitation records from 1945 to 1989 indicates that there is much greater spatial variability in precipitation trends compared to those for temperature, so it is not surprising that the Eclipse accumulation record does not 

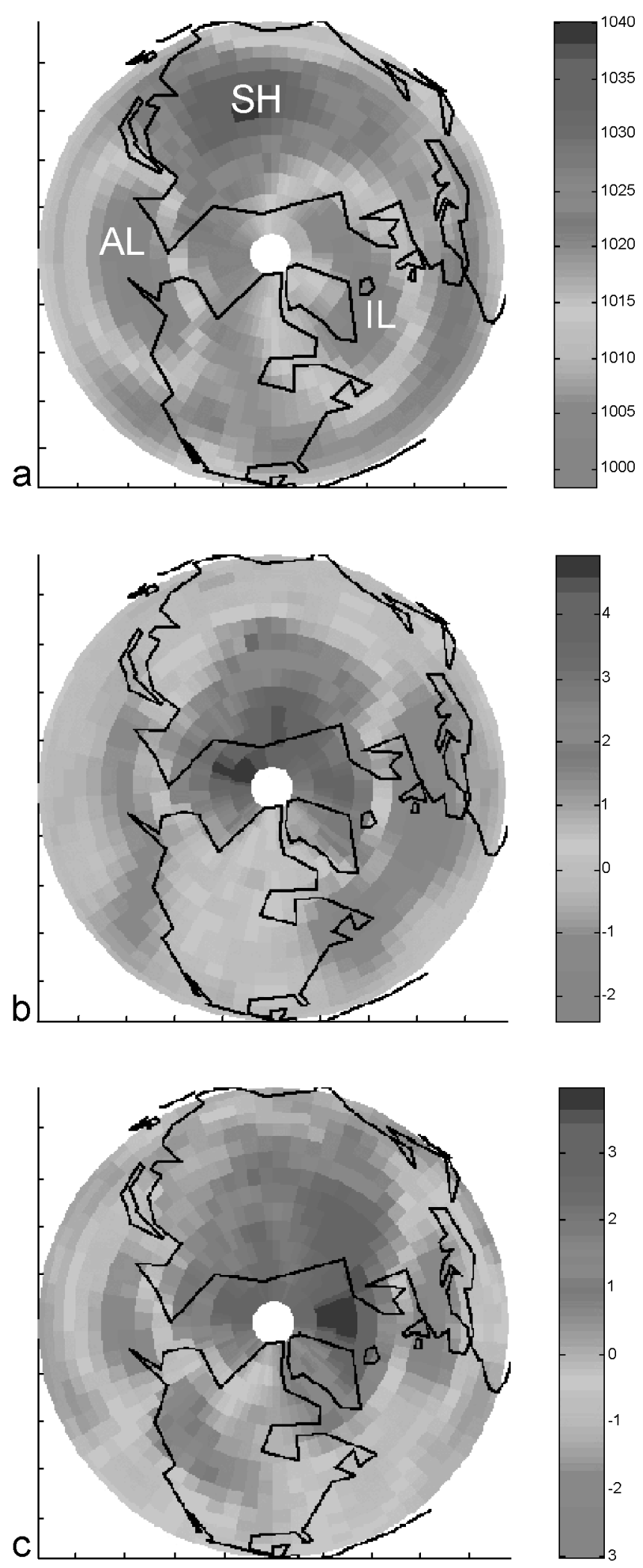

Fig. 5. (a) Mean Northern Hemisphere SLP (1945-95) in $5^{\circ} \times 5^{\circ}$ grid for winter (December-February) (after Trenberth and Paolino, 1980). The semi-permanent high- and lowpressure cells in winter (AL, Aleutian low; IL, Icelandic low; SH, Siberian high) are noted. (b) Mean SLPanomaly, 194595, for high winter sulfate concentrations (highest one-third) minus low winter sulfate concentrations (lowest one-third). (c) Same as (b) but for nitrate.

display a signal that is representative of station data over the entire region. In addition, the significant elevation gradient between the Eclipse site and lowland instrumental records may explain the limited usefulness of the Eclipse accumulation record as a proxy record for regional precipitation. In this case, orographic process may play a stronger role in controlling the amount of snowfall at Eclipse than regional climate variability. Or conversely, the station data reflect more local influences on precipitation, and the Eclipse record provides a more regional signal.

\section{Eclipse major ions and instrumental sea-level pressure records}

For reference, the mean SLP for the winter (DecemberFebruary) for the period 1945-95 is shown in Figure 5a. The semi-permanent high- and low-pressure cells for winter (Aleutian low, Icelandic low, Siberian high) are apparent. The $\delta^{18} \mathrm{O}$, accumulation and glaciochemical time series display significant correlations with the Northern Hemisphere SLP dataset. Here we focus on the relationship between the relative strength of the Aleutian low, and Siberian high, and non-volcanic (nv) sulfate (Yalcin and Wake, in press) and nitrate concentrations preserved in the Eclipse ice core since 1945. Since the 1940 s there has been an increase in nv sulfate and nitrate deposition in the Arctic linked to increases in anthropogenic emissions from Eurasia (Barrie, 1986; GotoAzuma and Koerner, 2001; Yalcin and Wake, 2001). In addition, there is considerable year-to-year variability in nv sulfate and nitrate deposition (Fig. 3) which is not the result of changes in source strength (annual anthropogenic emissions change by only a few per cent at most), but may be related to changes in atmospheric circulation and/or processes which affect the formation, transport and deposition of aerosols. To try to explain this year-to-year variability in terms of changes in atmospheric circulation, we looked at the difference between pressure patterns for years of high winter nv sulfate and nitrate (the highest one-third of concentrations) vs low winter nv sulfate and nitrate (the lowest onethird of concentrations). Winter values were used, as most of the increase in nitrate and nv sulfate over the last 50 years at Eclipse occurs in wintertime snow (Yalcin and Wake, 2001). Higher wintertime nv sulfate concentrations are associated with higher pressure of Siberia and the Siberian Sea (SLP 3-4 mbar higher; Fig. 5b) and lower pressure over the north (SLP 2 mbar lower; Fig. 5b). Higher wintertime nitrate concentrations correspond with higher pressure over Siberia and the Barents Sea (SLP 2-3 mbar higher; Fig. 5c), and lower pressure over Western Europe and in the Aleutian low (SLP 3 mbar lower; Fig. 5c). Note that these patterns of strengthening of the wintertime semi-permanent pressure cells by 24 mbar over the last 55 years shown in Figure $5 \mathrm{~b}$ and $\mathrm{c}$ are comparable to shifts in pressure associated with a changeover from a high to a low index for the North Atlantic Oscillation and ENSO. The increase in the pressure gradient resulting from the increase in SLP pressure over Eurasia, combined with decreased pressure in Western Europe/North Atlantic and in the region of the Aleutian low, would encourage the transport of pollutants from Eurasia into the northwestern North American Arctic (e.g. Raatz and Shaw, 1984). The results indicate that the year-to-year variability in sulfate and nitrate deposition can be linked to changes in atmospheric circulation, resulting from an increase in the wintertime intensity of semi-permanent pressure cells in the Northern Hemisphere, while the longer-term trends are related to changes in source strength in Eurasia (Goto-Azuma and Koerner, 2001; Yalcin and Wake, 2001). 


\section{GONGLUSIONS}

The 100 year physical and chemical time series developed from the Eclipse ice core provides a valuable new paleoclimate record for northwest North America. Comparison of the accumulation, $\delta^{18} \mathrm{O}$ and major-ion records with instrumental meteorological data indicates that there exist significant statistical relationships between the Eclipse glaciochemical time series and regional instrumental temperature data and Northern Hemisphere SLP data.

Summertime $\delta^{18} \mathrm{O}$ signals at Eclipse represent $5-10 \%$ of the temperature variability in northwestern North America. There exists little correlation between the Eclipse accumulation time series and instrumental precipitation data, reflecting substantial spatial variability of precipitation across the region. Perhaps the most encouraging results come from the analysis of SLP and the Eclipse nv sulfate and nitrate records. Winters with high sulfate and nitrate concentrations at Eclipse are related to a strengthening of the wintertime semi-permanent pressure cells in the Northern Hemisphere (i.e. Aleutian low, Icelandic low, Siberian high), which would encourage the transport of air from northern Eurasia into the region, indicating that both changes in source strength of pollutants and changes in atmospheric circulation must be considered to explain the observed trends.

Small dating errors in the Eclipse ice-core record may be influencing the results, although any dating error that may exist is not systematic through the entire record as the plus/ minus lag analysis did not reveal any improved relationships. Noise in the Eclipse ice-core time series may also be affecting the result of comparison to climate parameters. Constructing a stacked isotope/major-ion record using this core and cores collected in the near future from this region should improve correlations between the ice-core and climate records by increasing the signal-to-noise ratio. This approach has been used with considerable success for stableisotope records by Fisher and others (1996) and White and others (1997).

Comparison of the Eclipse with Mount Logan ice-core records highlights the importance of collecting ice cores from a range of elevations; time series developed from ice cores recovered from different elevations in the Saint Elias Mountains provide unique records of environmental change. In this sense, the Eclipse ice-core record, in addition to other snowpit and shallow-core studies (Holdsworth and others, 1988, 1991), provides an elevational survey that identifies the need for collecting ice cores from a range of elevations to more fully understand environmental change in northwestern North America. Glaciochemical and isotopic records developed over a range of elevations are essential for developing a fuller understanding of climate change in the region.

\section{AGKNOWLEDGEMENTS}

We thank E. W. Blake and S. Williams for assistance in drilling the core, D. Aulisio and C. Dunstan for assistance with core processing, S. I. Whitlow for major-ion analyses, D.
Meeker for assistance with the analysis of the SLP datasets, and D. A. Fisher for review of the manuscript. The Office of Polar Programs at the U.S. National Science Foundation supported this research.

\section{REFERENGES}

Barrie, L. A. 1986. Arctic air pollution: an overview of current knowledge. Atmos. Environ., 20(4), 643-663.

Blake, E.W., C. P. Wake and M. D. Gerasimoff. 1998. The ECLIPSE drill: a field-portable intermediate-depth ice-coring drill. f. Glaciol., 44(146), 175-178.

Dansgaard,W. 1964. Stable isotopes in precipitation. Tellus, 16(4), 436-468.

Fisher, D. A. and 7 others. 1996. Inter-comparison of $\delta^{18} \mathrm{O}$ and precipitation records from sites in Canada and Greenland over the last 3500 years and over the last few centuries in detail using EOF techniques. In Jones, P. D., R. S. Bradley and J. Jouzel, eds. Climatic variations and forcing mechanisms of the last 2000 years. Berlin, etc., Springer-Verlag, 297-328. (NATO ASI Series I: Global Environmental Change 41.)

Fisher, D. A. and 12 others. 1998. Penny Ice Cap cores, Baffin Island, Canada, and the Wisconsinan Foxe Dome connection: two states of Hudson Bay ice cover. Science, 279(5351), 692-695.

Goto-Azuma, K. and R. M. Koerner. 2001. Ice core studies of anthropogenic sulfate and nitrate trends in the Arctic. 7. Geophys. Res., 106(D5), 4959-4969.

Grumet, N. S. and 7 others. 2001. Variability of sea-ice in Baffin Bay over the last millennium. Climatic Change, 49(1-2), 129-145.

Hammer, C., P. A. Mayewski, D. Peel and M. Stuiver. 1997. Greenland Summit ice cores. Preface. F. Geophys. Res., 102(C12), 26,315-26,316.

Holdsworth, G. H. and H. R. Krouse. 2002. Altitudinal variation of the stable isotopes of snow in regions of high relief. F. Glaciol., 48(160), 31-41.

Holdsworth, G. and E. Peake. 1985. Acid content of snow from a midtroposphere sampling site on Mount Logan, Yukon Territory, Canada. Ann. Glaciol., 7, 153-160.

Holdsworth, G., M. Pourchet, F. A. Prantl and D. P. Meyerhof. 1984. Radioactivity levels in a firn core from the Yukon Territory, Canada. Atmos. Environ., 18(2), 461-466.

Holdsworth, G., H. R. Krouse and E. Peake. 1988. Trace-acid ion content of shallow snow and ice cores from mountain sites in western Canada. Ann. Glaciol., 10, 57-62.

Holdsworth, G., S. Fogarasi and H. R. Krouse. 1991. Variation of the stable isotopes of water with altitude in the St. Elias Mountains of Canada. $\mathcal{F}$. Geophys. Res., 96(D4), 7483-7494.

Holdsworth, G., H. R. Krouse and M. Nosal. 1992. Ice core climate signals from Mount Logan, Yukon A.D. 1700-1987. In Bradley, R. S. and P. D. Jones, eds. Climate since A.D. 1500. London, Routledge, 483-504.

Koerner, R. M. and D. A. Fisher. 1990. A record of Holocene summer climate from a Canadian high-Arctic ice core. Nature, 343(6259), 630-631.

Meeker, L. D., P. A. Mayewski and P. Bloomfield. 1995. A new approach to glaciochemical time series analysis. In Delmas, R. J., ed. Ice core studies of global biogeochemical cycles. Berlin, etc., Springer-Verlag, 383-400. (NATO ASI Series I: Global Environmental Change 30.)

Moore, G.W. K., G. Holdsworth and K. Alverson. 2001. Extra-tropical response to ENSO as expressed in an ice core from the Saint Elias mountain range. Geophys. Res. Lett., 28 (18), 3457-3460.

Raatz, W. E. and G. E. Shaw. 1984. Long-range transport of pollution aerosols into the Alaskan Arctic. F. Climate Appl. Meteorol., 23(7), 1052-1064.

Taylor, B. 1969. The summer climate of the St. Elias Mountains region. Montréal, Quebec, Arctic Institute of North America. (AINA Research Paper 53.)

Trenberth, K. E. and D. A. Paolino, Jr. 1980. The Northern Hemisphere sea level pressure data set: trends, errors and discontinuities. Mon. Weather Rev., 108, 855-872.

White, J.W. C. and 7 others. 1997. The climate signal in the stable isotopes of snow from Summit, Greenland: results of comparisons with modern climate observations. F. Geophys. Res., 102(C12), 26,425-26,439

Yalcin, K. and C.P. Wake. 2001. Anthropogenic signals recorded in an ice core from Eclipse Icefield, Yukon Territory, Canada. Geophys. Res. Lett., 28(23), 4487-4490.

Yalcin, K. and C. P. Wake. In press. A century of North Pacific volcanism in an ice core from Eclipse Icefield, Yulkon Territory, Canada. 7. Geophys. Res. 